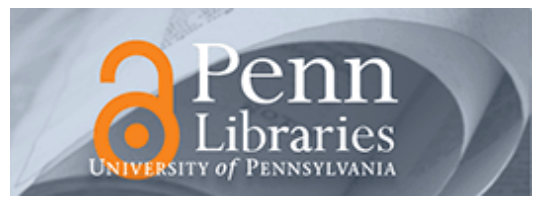

University of Pennsylvania

ScholarlyCommons

Finance Papers

Wharton Faculty Research

2003

\title{
Asset Prices and Business Cycles With Costly External Finance
}

Joao F. Gomes

University of Pennsylvania

Amir Yaron

University of Pennsylvania

Lu Zhang

Follow this and additional works at: https://repository.upenn.edu/fnce_papers

Part of the Finance Commons, and the Finance and Financial Management Commons

\section{Recommended Citation}

Gomes, J. F., Yaron, A., \& Zhang, L. (2003). Asset Prices and Business Cycles With Costly External Finance. Review of Economic Dynamics, 6 (4), 767-788. http://dx.doi.org/10.1016/

S1094-2025(03)00061-9

This paper is posted at ScholarlyCommons. https://repository.upenn.edu/fnce_papers/349

For more information, please contact repository@pobox.upenn.edu. 


\title{
Asset Prices and Business Cycles With Costly External Finance
}

\begin{abstract}
This paper asks whether the asset pricing fluctuations induced by the presence of costly external finance are empirically plausible. To accomplish this, we incorporate costly external finance into a dynamic stochastic general equilibrium model and explore its implications for the properties of the returns on key financial assets, such as stocks, bonds and risky loans. We find that the mean and volatility of the equity premium, although small, are significantly higher than those in comparable adjustment cost models.

However, we also show that these results require a procyclical financing premium, a property that seems at odds with the data.
\end{abstract}

Disciplines

Finance | Finance and Financial Management 
NBER WORKING PAPER SERIES

\title{
ASSET PRICES AND BUSINESS CYCLES WITH COSTLY EXTERNAL FINANCE
}

\author{
Joao Gomes \\ Amir Yaron \\ Lu Zhang
}

Working Paper 9364

http://www.nber.org/papers/w9364

\section{NATIONAL BUREAU OF ECONOMIC RESEARCH 1050 Massachusetts Avenue \\ Cambridge, MA 02138 \\ December 2002}

We have benefited from helpful comments from Ellen McGrattan, two anonymous referees, and Andy Abel, Joao Ejarque, Skander van den Heuvel, Urban Jermann, Sidney Ludvigson, Victor Rios-Rull, and seminar participants at Rochester, Wharton and at the C.V. Starr Conference in Macroeconomics and Finance. We are also indebted to Maria Vassalou and Chris Polk for providing us with their data. Financial support from the Rodney L. White Center for Financial Research is gratefully acknowledged. All remaining errors are our own. The views expressed herein are those of the authors and not necessarily those of the National Bureau of Economic Research.

(C) 2002 by Joao Gomes, Amir Yaron, and Lu Zhang. All rights reserved. Short sections of text, not to exceed two paragraphs, may be quoted without explicit permission provided that full credit, including $\mathbb{C}$ notice, is given to the source. 
Asset Prices and Business Cycles with Costly External Finance

Joao Gomes, Amir Yaron, and Lu Zhang

NBER Working Paper No. 9364

December 2002

\section{$\underline{\text { ABSTRACT }}$}

This paper asks whether the asset pricing fluctuations induced by the presence of costly external finance are empirically plausible. To accomplish this, we incorporate costly external finance into a dynamic stochastic general equilibrium model and explore its implications for the properties of the returns on key financial assets, such as stocks, bonds and risky loans. We find that the mean and volatility of the equity premium, although small, are significantly higher than those in comparable adjustment cost models. However, we also show that these results require a procyclical financing premium, a property that seems at odds with the data.

Joao Gomes

Finance Department

The Wharton School

University of Pennsylvania

Philadelphia, PA 19104

gomesj@wharton.upenn.edu
Amir Yaron

Finance Department

The Wharton School

University of Pennsylvania

Philadelphia, PA 19104

and NBER

yaron@wharton.upenn.edu

\section{Lu Zhang}

William E. Simon Graduate School of Business Administration

University of Rochester

Rochester, NY 14627

zhanglu@simon.rochester.edu 


\section{Introduction}

Models of costly external finance have enhanced the empirical performance of dynamic stochastic general equilibrium models. The richer internal propagation and amplification mechanism, induced by the presence of financing frictions, is typically able to replicate the observed hump-shape responses of the main macroeconomic aggregates to the underlying shocks in the economy.

In this paper we investigate the properties of the basic propagation mechanism in models of costly external finance. Specifically, we ask whether the asset pricing fluctuations induced by the presence of financing frictions are empirically plausible. Since the richer dynamics in this class of models are essentially driven by fluctuations in the value of financial assets, our approach provides an important alternative dimension for analyzing the properties of the propagation mechanism.

To accomplish this, we incorporate costly external finance into a specific dynamic stochastic general equilibrium model, developed by Bernanke and Gertler (1989), and studied in detail by Carlstrom and Fuerst (1997), and explore its implications for the properties of the returns on the key financial assets, such as stocks, bonds and risky loans. We then compare our findings with those of standard frictionless environments, with and without adjustment costs of investment.

Our findings are as follows. First, models with costly external finance deliver a premium on equity returns that is higher by a factor of 10 to 20, than comparable frictionless models, with or without adjustment costs. While this is still far from matching the observed equity premium, it does improve the performance of the baseline model significantly. Second, while the presence of financing frictions changes the dynamic properties of consumption, and hence of the relevant stochastic discount factor, the main force behind the larger premium is the 
much larger variations in stock returns in the presence of financing frictions. Third, as in a standard neoclassical model with convex adjustment costs in investment, the amplified fluctuations in stock returns are induced by movements in the price of capital, associated with the changes in the marginal costs to investment. Finally, however, we show that this behavior of marginal costs, which is also at the heart of the business cycle implications of the financing frictions model, requires procyclical movements in the default premium, a property not evident in the data.

The intuition for our results is simple. The empirical success of the costly external finance model lies in part in the fact that, for fixed amount of internal funds, more investment requires more borrowing, which raises monitoring costs and, consequently, the cost of external funds. It is this positive relation between investment and borrowing costs that generates an increase in marginal adjustment costs, and slows down capital accumulation, in the early stages of an expansion, thus making it possible to obtain hump-shaped responses to underlying shocks. However, while this rise in marginal costs helps to generate a large volatility in stock returns, it is necessarily associated with a procyclical rise in the default premium. Thus, the very mechanism behind the realistic movements in the key aggregates is also responsible for the models' shortcoming along the asset pricing dimension.

Our findings highlight the intimate link between the behavior of asset prices and the dynamic pattern of macro-economic aggregates. Accordingly, focusing on asset prices places important restrictions on the nature of the underlying financing frictions. Specifically, in the model studied here, financing constraints help generate richer dynamics for the typical macroeconomic aggregates; however, these constraints also seem to strain the model's ability to match certain key financial data.

The remainder of this paper is organized as follows. Section 2 describes the model. 
Section 3 contains our quantitative analysis and provides the intuition for many of our results. A final section offers some concluding remarks.

\section{Model}

In this section, we describe a general equilibrium model with costly external finance driven by endogenous agency costs. To allow us to investigate the asset pricing implications of this class of models, our setup is chosen to be as close as possible to that in Carlstrom and Fuerst (1997). This environment takes the stochastic growth model as its point of departure and modifies it by introducing financing constraints that contribute to distort optimal capital accumulation and thus generate a model with a much richer set of dynamics. The economy consists of a continuum of agents with unit mass. The agents are classified as households (fraction $1-\eta$ ) and entrepreneurs (fraction $\eta$ ). Entrepreneurs produce capital good and receive their external financing from a financial intermediary. In addition, our economy also includes firms that produce final consumption goods. For simplicity, producers of final goods do not face any financing constraints. We now examine the behavior of each one of these agents.

\subsection{Households}

Households are assumed to be infinitely lived agents with identical preferences represented by the function

$$
U=E_{0}\left[\sum_{t=0}^{\infty} \beta^{t} u\left(c_{t}, 1-l_{t}\right)\right] \quad 0<\beta<1
$$

where $\beta$ is the subjective discount factor and $c_{t}$ and $l_{t}$ denote, respectively, household consumption and hours worked, as a fraction of the total time endowment. Households derive income from renting labor and capital services at competitive rates, $w_{t}$ and $r_{t}$, respectively. 
Income can then be used to purchase consumption goods, at unit price, or additional capital, $a_{t+1}$, at price $q_{t}$. Accordingly, the household budget constraint is described by

$$
c_{t}+q_{t} a_{t+1}=w_{t} l_{t}+r_{t} a_{t}+q_{t}(1-\delta) a_{t}
$$

where $\delta$ is the rate of depreciation of capital. It follows that household choices are summarized by the conditions

$$
\begin{aligned}
U_{L}\left(c_{t}, 1-l_{t}\right) & =w_{t} U_{c}\left(c_{t}, 1-l_{t}\right) \\
U_{c}\left(c_{t}, 1-l_{t}\right) & =\beta E_{t}\left[U_{c}\left(c_{t+1}, 1-l_{t+1}\right) \frac{q_{t+1}(1-\delta)+r_{t+1}}{q_{t}}\right]
\end{aligned}
$$

In the financing frictions literature, the Euler equation is sometimes referred to as the demand for capital goods, or, simply, as investment demand.

\subsection{Entrepreneurs}

A fraction of consumers is also engaged in the production of capital goods. We call these agents entrepreneurs and assume that they have linear preferences characterized by the relation

$$
E_{0}\left[\sum_{t=0}^{\infty}(\beta \gamma)^{t} c_{t}^{e}\right] \quad 0<\gamma<1
$$

where $\beta \gamma$ is the entrepreneurs discount rate and $c_{t}^{e}$ denotes entrepreneurial consumption. Equation (5) embeds two assumptions. First, that entrepreneurs are risk neutral and, second, that they discount the future more heavily than households. Risk neutrality implies that entrepreneurs will care only about expected returns and will ensure that they will bear all risk, which simplifies considerably the financial contract below. The high rate of discount, on the other hand, guarantees that entrepreneurs are never sufficiently wealthy to overcome financing constraints. This requirement is formally equivalent to the more common 
assumption of exponential death.

As with households, entrepreneurs derive income from renting labor and capital services at competitive rates, $w_{t}^{e}$ and $r_{t}$, respectively. Since leisure does not enter their utility function, entrepreneurs devote their complete time endowment (1) to work. ${ }^{1}$ Accordingly, the total wealth, or net worth, of an entrepreneur is given by

$$
n_{t}=w_{t}^{e}+r_{t} a_{t}^{e}+q_{t}(1-\delta) a_{t}^{e}
$$

where $a_{t}^{e}$ denotes the capital holdings of the entrepreneur at the beginning of period $t$.

Each entrepreneur also earns additional income by investing $i_{t}$ units of consumption goods into a technology that produces $\omega_{t} i_{t}$ units of capital goods in the same period. ${ }^{2}$ We assume that $\omega_{t}$ is a random variable with positive support and is i.i.d, both across agents and over time, with mean 1 and variance $\sigma^{2}$. Also, let $\Phi(\cdot)$ and $\phi(\cdot)$ denote its cumulative distribution and density functions, respectively. Following the costly state-verification literature, we assume that $\omega_{t}$ is only observed by the entrepreneur. Outsiders can observe $\omega_{t}$ only by incurring a monitoring cost of $\mu i_{t}$ units of capital goods.

Investment can be financed by borrowing funds from financial intermediaries. However, the private information nature of the technology implies that this external finance is costly. Let $r_{t}^{l}$ denote the lending rate, in terms of capital goods, associated with this lending contract. ${ }^{3}$ Specifically, an entrepreneur who borrows $i_{t}-n_{t}$ units of consumption agrees to repay $\left(1+r_{t}^{l}\right)\left(i_{t}-n_{t}\right)$ in capital goods to the lender. However, if the realization of $\omega_{t}$ is too low, the entrepreneur will not be able to repay the loan and must default. This will

\footnotetext{
${ }^{1}$ Wage income ensures that entrepreneurs have strictly positive net worth in all periods, a necessary condition for the financial contracting problem to be well-defined.

${ }^{2}$ In other words, no aggregate uncertainty is revealed during the life of the project. As Carlstrom and Fuerst (1997) argue, this facilitates the sharing of risk in equilibrium.

${ }^{3}$ Gale and Hellwig (1985) and Williamson (1987) show that in environments of this type the optimal contract between lenders and entrepreneurs is characterized by risky debt.
} 
occur whenever

$$
\omega_{t}<\left(1+r_{t}^{l}\right)\left(i_{t}-n_{t}\right) / i_{t}=\bar{\omega}_{t}
$$

if the entrepreneur defaults the lender will monitor the project outcome and it will confiscate all the returns from the project. It follows that entrepreneurs in default must set their consumption, $c_{t}^{e}$, and holdings of next period capital, $a_{t+1}^{e}$, equal to 0 . For a successful entrepreneur however the budget constraint will be:

$$
q_{t} a_{t+1}^{e}+c_{t}^{e}=q_{t}\left(\omega_{t} i_{t}-\left(1+r_{t}^{l}\right)\left(i_{t}-n_{t}\right)\right)
$$

This implies that optimal decisions will satisfy the Euler equation:

$$
1=E_{t} \beta \gamma\left[\frac{q_{t+1}(1-\delta)+r_{t+1}}{q_{t}} R_{t+1}^{d}\right]
$$

where we define $R^{d}=\left(1+r^{l}\right) q \geq 1$ as the premium on external funds paid by the entrepreneur. ${ }^{4}$

\section{$2.3 \quad$ Financial Intermediaries}

Intermediaries allocate household savings by financing the investment projects of entrepreneurs. By funding a large number of entrepreneurs, intermediaries diversify projectspecific risk and, thus, guarantee a safe return to households, since there is no aggregate risk during the life of the project.

Given the assumptions above, the expected income of an intermediary that finances a project of size $i_{t}$ with an intra-period loan in the amount of $i_{t}-n_{t}$ is given by

$$
q_{t} i_{t} g\left(\bar{\omega}_{t}\right) \equiv q_{t}\left[\int_{0}^{\bar{\omega}_{t}} \omega_{t} i_{t} \Phi\left(d \omega_{t}\right)-\Phi\left(\bar{\omega}_{t}\right) \mu i_{t}+\left(1-\Phi\left(\bar{\omega}_{t}\right)\right)\left(1+r_{t}^{l}\right)\left(i_{t}-n_{t}\right)\right]
$$

\footnotetext{
${ }^{4}$ Since all risky loans are repaid within the period, the relevant risk free rate is 1.
} 
where

$$
g\left(\bar{\omega}_{t}\right) \equiv\left[\int_{0}^{\bar{\omega}_{t}} \omega_{t} \Phi\left(d \omega_{t}\right)-\Phi\left(\overline{\omega_{t}}\right) \mu+\left(1-\Phi\left(\bar{\omega}_{t}\right)\right) \bar{\omega}_{t}\right]
$$

is the fraction of the expected net output of capital goods collected by the lender.

\section{The Optimal Financial Contract}

At any point in time the expected income received by a typical entrepreneur is

$$
q_{t} i_{t} f\left(\bar{\omega}_{t}\right) \equiv q_{t}\left[\int_{\bar{\omega}_{t}}^{\infty}\left(\omega_{t} i_{t}-\left(1+r_{t}^{l}\right)\left(i_{t}-n_{t}\right)\right) \Phi\left(d \omega_{t}\right)\right]
$$

where $f\left(\bar{\omega}_{t}\right)$ is the share of production of capital goods received by entrepreneurs. Note that our definitions imply that $f\left(\omega_{t}\right)+g\left(\omega_{t}\right)=1-\Phi\left(\omega_{t}\right) \mu$, so that a fraction $\Phi\left(\omega_{t}\right) \mu$ of the produced capital is lost to monitoring costs.

The optimal financial contract between entrepreneurs and lenders can be summarized by solving the following problem:

$$
\begin{array}{ll} 
& \max _{r_{t}^{l}, \bar{\omega}_{t}} q_{t} i_{t} f\left(\bar{\omega}_{t}\right) \\
\text { s.t. } & q_{t} i_{t} g\left(\bar{\omega}_{t}\right) \geq\left(i_{t}-n_{t}\right)
\end{array}
$$

Intuitively, the contract is constructed to maximize entrepreneurial income, $q_{t} i_{t} f\left(\bar{\omega}_{t}\right)$, while satisfying the requirement that the financial intermediary receives an expected repayment, $q_{t} i_{t} g\left(\bar{\omega}_{t}\right)$ equal to that of its initial investment, $i_{t}-n_{t}$. It can be also shown that the contract satisfies a participation constraint for the entrepreneurs's, by guaranteeing a payoff at least as large as the amount of wealth invested, $n_{t}{ }^{5,6}$

\footnotetext{
${ }^{5}$ Remember that since all project returns are revealed within the period, there is no opportunity cost to the funds invested for both the entrepreneurs and the intermediaries.

${ }^{6}$ This formulation also requires the usual assumption that there is enough inter-period anonymity so that an entrepreneur's past history of debt repayment is not observed by future lenders and, thus, it does not affect any future contracts.
} 
The solution to (13) is a lending rate $r_{t}^{l}=\mathbf{r}^{l}\left(q_{t}, n_{t}\right)$ for each contract and a default threshold $\bar{\omega}_{t}=\boldsymbol{\omega}\left(q_{t}, n_{t}\right)$ such that entrepreneurs default (an lenders audit) whenever $\omega_{t}<\bar{\omega}_{t}$. With these variables at hand it is straightforward to use (7) to derive the amount of consumption goods investment in each project, $i_{t}=\mathbf{i}\left(q_{t}, n_{t}\right)$. Although the exact expressions are somewhat cumbersome it is fairly easy to show that the optimal level of the premium on external funds, $R^{d}$, is given by

$$
R^{d}=\frac{\bar{\omega}}{g(\bar{\omega})}
$$

Since monitoring costs, $\Phi(\bar{\omega}) \mu$, increase with the default threshold, $\bar{\omega}$, the payoff to the financial intermediary, $g(\bar{\omega})$, is less than proportional to $\bar{\omega}$. Hence, $R^{d}$ must always be an increasing function of the default threshold.

These optimal policy functions highlight the fact that the optimal financial contract depends on the model's general equilibrium conditions, through its effects on the level of entrepreneurial net worth, $n_{t}$, and through the aggregate price of capital, $q_{t}$. For example, holding net worth fixed, an increase in the price of capital goods increases investment spending, $i_{t}$, by entrepreneurs and, with it, borrowing requirements, $i_{t}-n_{t}$. This, in turn, drives the default threshold, $\bar{\omega}_{t}$, up, as well, and with it, the financing premium. Ceteris paribus, rising net worth lowers borrowing needs and, naturally, has the opposite effects on borrowing costs.

\subsection{Aggregation}

The linear nature of the capital goods and monitoring technologies imply that we can construct the aggregate, expected, production of capital goods by simply adding all the 
optimal investment policies of each entrepreneur

$$
\left.I\left(q_{t}, n_{t}\right) \equiv \int_{0}^{\infty} \omega \mathbf{i}\left(q_{t}, n_{t}\right) d \Phi\left(\omega_{t}\right)-\int_{0}^{\bar{\omega}_{t}} \mu \mathbf{i}\left(q_{t}, n_{t}\right) d \Phi\left(\omega_{t}\right)=\mathbf{i}\left(q_{t}, n_{t}\right)\left[1-\mu \Phi\left(\bar{\omega}_{t}\right)\right)\right]
$$

Equation (15) implies that only the first moment of the distribution of net worth, $n_{t}$, has any effect on the aggregate economy, thus avoiding the need to keep track of the entire cross-section distribution of net worth across entrepreneurs. Equation (15) is often referred as the supply curve for capital goods. Carlstrom and Fuerst (1997) show that this capital supply function is increasing in both the price of capital goods, $q_{t}$, and the level of net worth, $n_{t}$. While the positive slope in $q_{t}$ is a standard feature in models with standard, convex, adjustment costs, the agency problem leads investment to also be increasing in the amount of internal funds available to the entrepreneur. Thus changes in net worth will lead to movements in the supply of capital goods, for a given price $q_{t}$.

As we will see below, the monotonicity in $q_{t}$ will play an important role in the asset pricing implications of our model. Intuitively this is motivated by the rise in financing costs when investment increases, holding net worth fixed. The corresponding rise in borrowing requirements drives up default rates and agency costs, which increases the marginal costs to investment and thus $q_{t}$, i.e., the value of existing capital goods.

\subsection{Final Goods Producers}

The final element in our economy is the set of competitive firms engaged in the production of consumption (and investment) goods, $Y_{t}$, using a constant-return-to-scale production function

$$
Y_{t}=\theta_{t} F\left(K_{t}, H_{t}, H_{t}^{e}\right)
$$


Here $K_{t}=(1-\eta) a_{t}+\eta a_{t}^{e}$ is the aggregate level of capital, $H_{t}$ denotes the aggregate supply of household labor, $H_{t}^{e}$ denotes the aggregate supply of entrepreneurial labor. The optimality conditions for these firms are given by

$$
\begin{aligned}
r_{t} & =\theta_{t} F_{K}\left(K_{t}, H_{t}, H_{t}^{e}\right) \\
w_{t} & =\theta_{t} F_{H}\left(K_{t}, H_{t}, H_{t}^{e}\right) \\
w_{t}^{e} & =\theta_{t} F_{H^{e}}\left(K_{t}, H_{t}, H_{t}^{e}\right)
\end{aligned}
$$

\subsection{Competitive Equilibrium}

A competitive equilibrium satisfies the following market clearing conditions

- Labor market

$$
\begin{aligned}
& H_{t}=(1-\eta) l_{t} \\
& H_{t}^{e}=\eta
\end{aligned}
$$

- Capital goods market

$$
K_{t+1}=(1-\delta) K_{t}+I\left(q_{t}, n_{t}\right)
$$

- Final goods market

$$
Y_{t}=(1-\eta) c_{t}+\eta c_{t}^{e}+\eta i_{t}
$$

\subsection{Asset Returns}

With the competitive equilibrium characterized it is easy to construct the returns, and prices, of any assets. Specifically, we are interested in characterizing the returns on equity and different types of debt. 
Regarding equity we can define two types of assets: household and entrepreneurs' capital. Given that entrepreneurs hold only a very small fraction of the wealth in the economy we will focus on household capital. ${ }^{7}$ The model described above is formally equivalent to one where household capital is owned by final goods producers and where households own stocks on these firms. Hence, in equilibrium, the value of household capital in our current formulation is equivalent to the stock market value of final goods producers in the alternative set-up. Using the household Euler equation (4) this return can be defined as ${ }^{8}$

$$
R_{t, t+1}^{K}=\frac{q_{t+1}(1-\delta)+r_{t+1}}{q_{t}}
$$

In addition, since households face no borrowing constraints they can borrow and lend freely among themselves or directly from the financial intermediaries. It follows that we can use the household's marginal rate of substitution to define the (implicit) risk free rate for this economy as

$$
R_{t, t+1}^{F}=\frac{1}{E_{t}\left[M_{t, t+1}\right]}
$$

where $M_{t, t+1}=\beta \frac{U_{c}\left(c_{t+1}, 1-l_{t+1}\right)}{U_{c}\left(c_{t}, 1-l_{t}\right)}$ is the marginal rate of substitution or the stochastic discount factor for this economy.

\section{Results}

The quantitative analysis of our model is aimed at examining the asset pricing implications of prototypical agency cost models. Accordingly we first start by calibrating the model and then proceed to solve the model using the well known method of taking a log-linear expansion around the deterministic steady-state. We then document some of the model's

\footnotetext{
${ }^{7}$ In any event the two returns behave almost identically in all of our examples below.

${ }^{8}$ Since households have an interior solution for asset holdings, the Euler equation (4) can be used to determine asset prices.
} 
more successful implications for the study of business cycle fluctuations. Finally we provide a careful examination of its key implications for asset pricing.

\subsection{Calibration}

Our calibration procedure is designed to facilitate the comparison with the existing quantitative studies on business cycle fluctuations in the context of agency cost models. Accordingly, our benchmark choices closely replicate those proposed by Carlstrom and Fuerst (1997). We begin by assuming that the utility function for households is of the form

$$
U=\frac{c^{1-\sigma}-1}{1-\sigma}+A(1-l)
$$

where the parameter $A$ is picked so that the steady-state level of hours is equal to 0.3 . The rate of intertemporal preference is set at $\beta=0.99$. The risk aversion parameter $\sigma$ is initially set at 1 , but we also examine the case where it is equal to 5 .

The production of final goods is assumed to be of the Cobb-Douglas form

$$
Y=\theta_{t} K_{t}^{\alpha_{k}} H_{t}^{\alpha}\left(H_{t}^{e}\right)^{\alpha_{e}}
$$

and the technology shock, $\theta$, follows the mean reverting process

$$
\theta_{t+1}=0.05+0.95 \times \theta_{t}+\varepsilon_{t}
$$

and $\varepsilon_{t} \sim N\left(0,0.01^{2}\right)$. The output elasticities are equal to, respectively $\alpha_{k}=0.36$, $\alpha_{h}=0.6399$, and $\alpha_{h^{e}}=0.0001$. The share needs to be positive so that entrepreneurs have positive net worth with probability one. Nevertheless, the share of entrepreneur labor is deliberately chosen so that labor income plays a very minor role both in determining net 
worth and income distribution in our model. ${ }^{9}$

The distribution of investment outcomes, $\Phi(\cdot)$ is assume to be lognormal, and the monitoring cost, $\mu$, in our benchmark calibration is set equal to $0.25 .{ }^{10}$ For robustness we also examine the results of setting $\mu=0.05$, the lower bound of most empirical estimates of bankruptcy costs (Warner (1977)). As in Carlstrom and Fuerst (1997), the entrepreneurs (additional) rate of discount, $\gamma$, is selected to imply an annualized default premium of 187 basis points, the average spread between the prime rate and the rate on 3-month commercial paper for the period between 1971 and 1996. Finally the rate of depreciation of capital equals $\delta=0.02$.

\subsection{Business Cycle Results}

Agency cost models, and, more generally, models with financing frictions, usually enhance significantly the empirical performance of dynamic stochastic general equilibrium models. Figure 1 illustrates this by depicting the impulse responses of the main macroeconomic variables to a technology shock in our agency costs environment and in a standard neoclassical growth model with convex adjustment costs. The adjustment cost model is calibrated so that in steady-state the ratio of adjustment costs to investment spending is exactly identical to the share of financing costs in investment for the costly external finance model. ${ }^{11}$

As can be seen from Figure 1, in the presence of agency costs, output, investment, and hours worked exhibit a hump-shape pattern that reflects a delayed response to the shock that is entirely missing in the pure adjustment cost model. It is this more realistic feature

\footnotetext{
${ }^{9}$ Our results are independent of the choice for the share of entrepreneurs in the population, $\eta$.

${ }^{10}$ Following the results in Altman (1984), Carlstrom and Fuerst (1997) argue that this is a reasonable estimate of the total (direct and indirect) costs of bankruptcy.

${ }^{11}$ Formally adjustment costs are captured by including the term $\frac{a}{2}\left(\frac{I}{K}\right)^{2} K$ in the capital accumulation equation and picking $a$ to satisfy $\frac{a \delta}{2}=\Phi(\bar{\omega}) \mu$.
} 
of the model that make for much of its current appeal amongst researchers and provides for a promising source for future studies. The hump shape and delayed investment result in noticeable persistence in the auto-correlation function for output and investment growth features that Cogley and Nason (1995) document are key stylized features in the data, and that the typical real-business cycle model has great difficulty replicating. ${ }^{12}$

Essentially, the intuition behind this result has to do with the fact, much like in an environment with convex adjustment costs, the increase in investment, induced by a positive technology shock, brings about an increase in the marginal cost of investment. This increase in marginal costs is a consequence of the increase in agency costs. Since almost all of entrepreneurial net worth comes from capital, which is initially fixed, the increase in investment must be almost entirely financed with external funds, which raises borrowing costs. After the initial periods, as entrepreneurial capital, and with it net worth, rises, the role of external finance declines and so do the marginal costs of investing. It is the endogenous pattern of net worth that leads to an endogenous adjustment in marginal costs, and hence to the hump-shaped response of the main macro aggregates. This feature is absent in most simple adjustment cost models. ${ }^{13}$

Finally, this improvement in conditional moments does not compromise the model's ability to replicate the standard business cycle facts. Table 1 illustrates this by comparing

\footnotetext{
${ }^{12}$ Although these results apply to the theoretical variables defined above they are not exactly comparable with the actual US data. We can obtain more meaningful comparisons by combining the equilibrium conditions for both goods markets to obtain

$$
Y_{t}+Y_{t}^{f}=C_{t}+X_{t}
$$

where $C_{t}=(1-\eta) c_{t}+\eta c_{t}^{e}$ denotes aggregate consumption, $X_{t}=\eta\left(K_{t+1}-(1-\delta) K_{t}\right)$ is investment spending and the monitoring cost term, $Y_{t}^{f}=\mathbf{i}\left(q_{t}, n_{t}\right) \mu \Phi\left(\bar{\omega}_{t}\right)$, can be interpreted as the output of financial services, so that $Y_{t}+Y_{t}^{f}$ denotes the total value of goods and services produced in this artificial economy. These series can then be mapped to the standard macro aggregates. Given our focus on asset prices, to maintain comparability with the existing literature, we do not pursue this issue here.

${ }^{13}$ Boldrin, Christiano and Fisher (2001) examine an environment where the reallocation of goods to the investment sector takes one period, which also implies that adjustment costs are very high initially.
} 
key unconditional moments generated from the model's stationary distribution with those obtained from a standard quadratic adjustment cost model. Given their identical steadystate implications, the close match in the volatilities of the key macroeconomic variables allows us to proceed by focusing on their asset pricing implications.

\subsection{Asset Returns Implications}

As we have seen, the empirical success of the model depends crucially on the behavior of the marginal cost of investment during the adjustment of the economy to the underlying shocks. However, the nature of these adjustment costs is closely linked to the presence of agency costs and the behavior of key financial variables. Thus, it seems important to ask whether the fluctuations in marginal adjustment costs, that form the basic propagation mechanism in these models, is empirically plausible. Specifically, in this section, we investigate how the key asset pricing implications of the stochastic growth model change in the presence of costly external finance.

Table 2 shows the basic properties of asset returns in our costly external finance environment. For comparison purposes we also provide the results for a standard neoclassic growth model with and without adjustment costs. In all scenarios we consider the effects of increasing the risk aversion coefficient, $\sigma$, from the benchmark value of 1 to 5 . In addition, we also examine the effects of alternative degrees of both financing and standard adjustment costs to investment. Financing costs can be regulated by adjusting the level of monitoring costs, $\mu$.

As is now well known, increases in risk aversion work to raise the equity premium, by raising the volatility for the stochastic discount factor, $M_{t, t+1}$. This is true in all cases examined in Table 2. Moreover, since our model does not allow for any trend in consumption, 
the higher volatility in the stochastic discount factor also produces a lower level for the risk free rate, $R_{t, t+1}^{F}$. Jermann (1998) and Boldrin, Christiano and Fisher (2001) show that introducing costs to the adjustment of the capital stock improves the asset pricing performance of the basic model by raising both the volatility of consumption and that of stock returns. Table 2 shows, however, that introducing costly external finance increases the value of the premium on equity returns by a factor of about 11 relative to the convex adjustment cost scenario — which is about twice that of the standard real business cycle model. $^{14}$

A more detailed examination is provided in Table 3. It shows the basic properties of the pricing kernel and stock returns under several different scenarios. While standard "physical" adjustment costs generate higher equity premium by raising the volatility of consumption growth and returns in similar proportions, the effects of financing costs are quite different. Clearly the presence of costly external finance further increases the volatility of the pricing kernel, above and beyond the level generated by standard adjustment costs. Nevertheless, the principal mechanism through which the model raises the equity premium, is by raising the variance (although not the Sharpe ratio) of stock returns significantly.

Table 3 also provides information on the behavior of the premium on external finance, $R_{t, t+1}^{d}$. Recall that this premium is only relevant for entrepreneurial loans and is thus not priced by the households stochastic discount factor, $M_{t, t+1}$. Regardless, as Table 3 suggests, this financing premium behaves very much like the returns on stocks in this model.

Table 4 provides more detailed decomposition on the role of each of these changes on the level of equity premium. Taking as a benchmark the basic stochastic growth model, the

\footnotetext{
${ }^{14}$ Although these equity premium numbers are still rather small they are similar to those documented by Lettau (2002). Jermann (1998) shows that habit formation and somewhat larger adjustment costs can significantly magnify the model's equity premium to match that in US data.
} 
second line in the Table reports the value of the equity premium due to the introduction of standard convex adjustment costs. The remaining rows look into the role of financing frictions. First, we try to isolate the role of the pricing kernel, by computing the theoretical value of the equity premium in a world where the marginal rate of substitution, $M_{t, t+1}$, reflects the presence of financing constraints, but where stock returns are still those of an economy with physical adjustment costs. As can be seen, this effect alone roughly doubles the value of the equity premium to about 6 basis points. Nevertheless this value is far smaller than the actual premium generated in the agency cost economy.

The next to last row tries to isolate the effects of the financing premium, $R^{d}$, on stock returns, $R^{k}$. This row reports the hypothetical value of the equity premium, when the default premium is not allowed to change over the cycle. ${ }^{15}$

The results show that without the variation in the financing premium, the equity premium actually disappears! In other words, it is only due to the cyclical nature of the premium on external funds, that the financing cost model is capable of improving the asset pricing performance of the neoclassical growth model. As we will see below, however, these cyclical properties of the financing premium do not seem to be supported by the data. ${ }^{16}$

\subsection{The Role of the Financing Premium}

Given the intimate link between equity and financing premiums, we now take a closer look at the latter. Figure 2 shows the impulse responses of the main financial variables, following a positive innovation to the level of technology. Shown are the response of stock returns,

\footnotetext{
${ }^{15}$ Specifically, it reports the excess stock returns, relative to risky loans, from the perspective of households. This premium provides a measure of the component of stock returns not directly linked to fluctuations in the financing premium.

${ }^{16}$ More formally, in this model both $R^{d}$ and $R^{k}$ share a common risk factor. Our results show that the compensation for the risks driving the financing premium is almost identical to that for stocks. Hence, the premium on stocks not linked to changes in the financing premium is quite small.
} 
$R^{k}$, the default premium, $R^{d}$, and its main determinants, the value of Tobin's $q$, and the investment to net worth ratio $i / n$.

Except for magnitude, the response of the stock return resembles that obtained in the standard convex adjustment cost model. It essentially traces the movements in the marginal productivity of capital. In the presence of rising marginal costs to investment this response is significantly amplified by the increase in the price of capital goods, $q$. As discussed in section 2.4 , in the context of our financing cost model, this rising marginal cost is due to an increase in borrowing costs. As entrepreneurs increase their indebtedness to finance new investment, the default threshold rises and, from equation (14), this leads to a higher premium on external funds. It follows that the strong response of stock returns in the agency cost model can only be obtained with a strong increase of the default premium in periods of economic expansion. Moreover, as Table 4 has shown, without this procyclical behavior of the financing premium the agency cost model is unable to produce a positive equity premium. ${ }^{17}$

\subsection{Asset Returns and Pricing Factors}

An alternative way to understand the asset pricing implications of the model is to look at the link between stock prices and business cycle indicators. In particular, there is an extensive literature documenting that stock returns lead the cycle (for example, Fama and Gibbons (1982) and Cochrane (1991)). To accomplish this we can rewrite equation (24) as

$$
R_{t, t+1}^{k}=\frac{M P K_{t+1}+(1-\delta) \times q\left(\frac{i_{t+1}}{K_{t+1}}, \frac{n_{t+1}}{K_{t+1}}\right)}{q\left(\frac{i_{t}}{K_{t}}, \frac{n_{t}}{K_{t}}\right)} .
$$

\footnotetext{
${ }^{17}$ This procyclical variations seem to accord better with a recent strand of literature that emphasizes enforceability, limited commitment and the cyclical variation in outside options (for example, Kehoe and Levine (1993), Kotcherlakotta (1996), Zhang (1997), Alvarez and Jermann (2000), Albuquerque and Hopenhayn (2001), Clementi and Hopenhayn (2001), Cooley, Quadrini, and Marimon (2001)).
} 
Equation (26) shows that the dynamics of the stock return in our economy are completely driven by three aggregate, or macroeconomic, factors: productivity, $M P K$, the investment to capital ratio, $i / K$, and the net worth to capital, $n / K$. Accordingly, Figure 3 displays the correlations between $R^{k}$ with various leads and lags of investment/capital (Panel A) and productivity (Panel B). For comparison we also show the same results for our benchmark convex adjustment cost model as well as the corresponding values for the U.S. in the period between 1952-1999, using the NYSE value weighted returns. ${ }^{18}$

The figure shows that the financing cost model is generally better able to replicate the both the level and the dynamic pattern of the cross-correlations observed in the data. Most notably, the level of the correlations for the standard convex adjustment cost model is almost always far too high. The financing cost model, on the other hand, is usually quite close to the empirical values of the correlations. In addition, the agency cost model also seems to replicate the $V$-like shape observed in the dynamic pattern of the empirical investment correlations. The convex adjustment costs model, however, generates an inverted $V$-like shape. Regarding the productivity correlations, the adjustment costs model still produces correlations that are too large, but their dynamic pattern seems to be better aligned with the data. The correlations of the financing costs, however, has a pronounced $V$-shape that is not present in the data. Figure 4 confirms that these findings are quite robust to alternative choices for the adjustment and financing costs parameters.

Finally, Figure 5 reveals the mechanism that governs the dynamic pattern of these correlations. Panels A and B compare the financing premium in the model with an empirical measure of the premium on external funds - the default premium defined as the spread between Baa and Aaa bonds. As we have documented above, the model implies that

\footnotetext{
${ }^{18}$ Naturally, since $R^{k}$ is independent of all financing variables in the standard convex adjustment cost model, all correlations with $n / K$ are zero.
} 
the behavior of the financing premium is strongly pro-cyclical, while in both panels, the empirical default premia seems quite countercyclical. Figure 6 reports the same results for the case where the default premium is measured as the spread between the prime rate and the rate on 3-month commercial paper. Here too the observed default premium is clearly countercyclical. Finally, Figure 7 examines the robustness of our findings by comparing the model's implications with alternative measures of financing costs, constructed by Lamont, Polk, and Saa-Requejo (2001) and Vassalou and Xing (2002). ${ }^{19}$ While these measures have somewhat different properties, it is clear that they are both slightly countercyclical, or at best, fairly acyclical.

\section{Conclusions}

In this paper we analyzed the asset pricing properties of business cycle models that focus on costly external finance to improve the internal propagation mechanism in standard business cycle models. As we document in the text, this class of models has more realistic business cycle properties, particularly with respect to the cyclical pattern of the key macroeconomic variables. In particular, the richer endogenous dynamics allow these models to match the observed hump-shape response of many aggregate quantities to the underlying shocks.

The asset pricing implications of these models however are not as well understood. We show that, much like the dynamics of the key macro aggregates, they seem to be driven by the properties of the premium on external funds. The behavior of this financing premium maps almost exactly into the properties of the returns to capital, and, as a result, contributes to produce equity premiums that are both larger and more volatile, than those in comparable

\footnotetext{
${ }^{19}$ The common factor in Lamont, Polk, and Saa-Requejo (2002) is the return spread of financially constrained firms over less constrained firms, quantified using the methodology of Kaplan and Zingales (1997). Vassalou and Xing (2002) estimate default likelihood indicators for individual firms following the methodology of Merton (1974). The aggregate default likelihood measure is then defined as a simple average of the default likelihood indicators of all firms.
} 
convex adjustment cost models. While both of these properties are also significant and desirable improvements over the standard neoclassical model, they are almost entirely driven by a strongly procyclical financing premium - a feature that is at odds with the data. Intuitively, the problem is the positive association between investment and borrowing costs, also the crucial element in generating the hump-shaped response of the main macro variables. As a consequence, periods of high productivity (and returns) are also periods of high investment, borrowing requirements and, as a consequence, high borrowing costs.

The results in this paper cast some doubts on the use of models with costly external finance to explain the observed movements in aggregate variables, More importantly, however, our analysis provides an important new dimension to investigate the empirical success of alternative models of financing frictions. Thus, our approach could be used to distinguish between competing theories of the source of financing constraints, or to motivate the introduction of additional features such as multiperiod debt, time to build (or to finance) and time variation in conditional default probabilities. 


\section{References}

[1] Albuquerque, Rui and Hugo Hopenhayn, Optimal Lending Contracts and Firm Dynamics, Working Paper, University of Rochester, May 2001.

[2] Altman, Edward I., 1984, A Further Investigation of the Bankruptcy Cost Question, Journal of Finance, 39 (4), 1067-1089.

[3] Alvarez, Fernando, and Urban J. Jermann, 2000, Efficiency, Equilibrium, and Asset Pricing With Risk of Default, Econometrica, 68 (4), 775-797.

[4] Bernanke, Ben and Mark Gertler, 1989, Agency Costs, Net Worth, and Business Fluctuations, American Economic Review, 79 (1), 14-31.

[5] Bernanke, Ben, Mark Gertler, and Simon Gilchrist, 1996, The Financial Accelerator and the Flight to Quality, Review of Economics and Statistics, 78, 1-15.

[6] Bernanke, Ben, Mark Gertler, and Simon Gilchrist, 1999, The Financial Accelerator in a Quantitative Business Cycle Framework, in Handbook of Macroeconomics, Edited by Michael Woodford and John Taylor, North Holland.

[7] Boldrin, Michele, Lawrence J. Christiano, and Jonas D. M. Fisher, 2001, Habit Persistence, Asset Returns, and the Business Cycle, American Economic Review, 91 (1), 149-166.

[8] Carlstrom, Charles T., and Timothy S. Fuerst, 1997, Agency Costs, Net Worth, and Business Fluctuations: A Computable General Equilibrium Analysis, American Economic Review, 87 (5), 893-910.

[9] Clementi, Gian Luca, and Hugo Hopenhayn, 2001, Optimal Lending Contracts and Firms' Survival with Moral Hazard, unpublished manuscript, University of Rochester

[10] Cochrane, John H., 1991, Production-Based Asset Pricing and the Link Between Stock Returns and Economic Fluctuations, Journal of Finance, 46 (1), 209-237.

[11] Cogley, Timothy, and James M. Nason, 1995, Output Dynamics in Real-Business-Cycle Models, American Economic Review, 85 (3), 492-511.

[12] Cooley, Thomas F., Vincenzo Quadrini, and Ramon Marimon, 2001, Aggregate Consequences of Limited Contract Enforceability, Working Paper, Stern School of Business, New York University. 
[13] Fama, Eugene F., and Michael R. Gibbons, 1982, Inflation, Real Returns and Capital Investment, Journal of Monetary Economics, 9, 297-323.

[14] Gale, Douglas, and Martin Hellwig, 1985, Incentive-Compatible Debt Contracts: The One-Period Problem, Review of Economic Studies, LII, 647-663.

[15] Gomes, Joao F., Amir Yaron, and Lu Zhang, 2002, Asset Pricing Implications of Firms' Financing Constraints, Working Paper, The Wharton School, University of Pennsylvania.

[16] Jermann, Urban J., 1998, Asset Pricing in Production Economies, Journal of Monetary Economics, 41, 257-275.

[17] Kaplan, Steve and Luigi Zingales, 1997, Do Financing Constraints Explain why Investment is Correlated with Cash-Flow, Quarterly Journal of Economics, 112 (1), $168-216$.

[18] Kehoe, Timothy, and David K. Levine, 1993, Debt-Constrained Asset Markets, Review of Economic Studies, 60, 868-888.

[19] Kiyotaki, Nobuhiro, and John Moore, 1997, Credit Cycles, Journal of Political Economy, 105 (2), 211-248.

[20] Kocherlakota, Narayana R., 1996, Implications of Efficient Risk Sharing Without Commitment, Review of Economic Studies, 63, 595-609.

[21] Lamont, Owen, Christopher Polk and Jesús Saá-Requejo, 2001, Financial Constraints and Stock Returns, Review of Financial Studies, 14 (2), 529-554.

[22] Lettau, Martin, 2002, Inspecting the Mechanism: Closed-Form Solutions for Asset Prices in Real Business Cycle Models, Forthcoming, The Economic Journal.

[23] Merton, Robert C., 1974, On the Pricing of Corporate Debt: The Risk Structure of Interest Rates, Journal of Finance, 29, 449-470.

[24] Warner, Jerald, 1977, Bankruptcy Costs: Some Evidence, Journal of Finance, 32 (2), 337-348.

[25] Williamson, Stephen, 1987, Financial Intermediation, Business Failures, and Real Business Cycles, Journal of Political Economy, 95 (6), 1196-1216.

[26] Zhang Harold, 1997 Endogenous Borrowing Constraints with Incomplete Markets. Journal of Finance, 52, 2187-2205. 


\section{Table 1 : Business Cycle Properties}

This table reports the relative standard deviation of consumption, investment and hours to the standard deviation of output. The data is quarterly from 1959.1-1999.4, using a deterministic trend.

\begin{tabular}{lccc}
\hline \hline Model & $\sigma_{c} / \sigma_{Y}$ & $\sigma_{i} / \sigma_{Y}$ & $\sigma_{H} / \sigma_{Y}$ \\
\hline Data & 0.51 & 2.65 & 0.92 \\
Adjustment Costs & 0.71 & 2.41 & 0.49 \\
Costly External Finance & 0.68 & 2.51 & 0.54 \\
\hline
\end{tabular}

Table 2 : Asset Pricing Results

This table reports the annualized (log) risk free rate and the $(\log )$ equity premium on household capital. The risk free rate is defined as $1 / E_{t}\left[M_{t+1}\right]$ where $M$ is the intertemporal marginal rate of substitution for the households. The equity premium is defines as the difference between the (log) return to household capital and the $(\log )$ risk free rate defined above. All the moments are in percentage.

\begin{tabular}{|c|c|c|}
\hline Model & $E\left[r_{t, f}\right]$ & $E\left[r_{t, t+1}^{k}-r_{t, f}\right]$ \\
\hline \multicolumn{3}{|c|}{ Standard Growth Model } \\
\hline$\sigma=1$ & 4.016 & 0.001 \\
\hline$\sigma=5$ & 4.008 & 0.001 \\
\hline \multicolumn{3}{|c|}{ Adjustment Costs } \\
\hline$\sigma=1, a=0.122$ & 4.014 & 0.001 \\
\hline$\sigma=5, a=0.122$ & 4.005 & 0.002 \\
\hline$\sigma=1, a=20$ & 3.997 & 0.004 \\
\hline \multicolumn{3}{|c|}{ Costly External Finance } \\
\hline$\sigma=1, \mu=0.25$ & 4.001 & 0.017 \\
\hline$\sigma=5, \mu=0.25$ & 3.988 & 0.022 \\
\hline$\sigma=1, \mu=0.05$ & 4.006 & 0.012 \\
\hline
\end{tabular}




\section{Table 3 : Volatility}

This table reports the volatility of the (log) pricing kernel, $m_{t+1}=\log \left[\beta \frac{U_{c}\left(c_{t+1}, 1-l_{t+1}\right)}{U_{c}\left(c_{t}, 1-l_{t}\right)}\right]$, denoted $\sigma\left(m_{t+1}\right)$, and volatility $\sigma\left(r_{t, t+1}^{k}\right)$ and Sharpe ratio $S\left(r_{t, t+1}^{k}\right)$ of the (log) return to capital (owned by households), $r_{t, t+1}=\log R_{t, t+1}^{k}$, and the (log) financing premium, $r_{t, t+1}^{d}=\log R_{t, t+1}^{d}$. Also included is the covariance of the return on capital and the pricing kernel. All numbers, except the Sharpe ratios, are in percentage.

\begin{tabular}{|c|c|c|c|c|c|}
\hline Model & $\sigma\left(m_{t+1}\right)$ & $\sigma\left(r_{t, t+1}^{k}\right)$ & $\operatorname{cov}\left(m_{t+1}, r_{t, t+1}^{k}\right)$ & $\sigma\left(r_{t, t+1}^{d}\right)$ & $S\left(r_{t, t+1}^{k}\right)$ \\
\hline \multicolumn{6}{|c|}{ Standard Growth Model } \\
\hline$\sigma=1$ & 0.880 & 0.119 & -0.001 & 0 & 0.008 \\
\hline$\sigma=5$ & 1.572 & 0.082 & -0.001 & 0 & 0.015 \\
\hline \multicolumn{6}{|c|}{ Adjustment Costs } \\
\hline$\sigma=1, a=0.122$ & 1.098 & 0.135 & -0.002 & 0 & 0.010 \\
\hline$\sigma=5, a=0.122$ & 1.744 & 0.095 & -0.002 & 0 & 0.017 \\
\hline$\sigma=1, a=20$ & 2.153 & 0.200 & -0.004 & 0 & 0.021 \\
\hline \multicolumn{6}{|c|}{ Costly External Finance } \\
\hline$\sigma=1, \mu=0.25$ & 1.971 & 1.256 & -0.025 & 1.274 & 0.013 \\
\hline$\sigma=5, \mu=0.25$ & 2.556 & 1.115 & -0.029 & 1.157 & 0.020 \\
\hline$\sigma=1, \mu=0.05$ & 1.709 & 0.989 & -0.017 & 1.318 & 0.012 \\
\hline
\end{tabular}

\section{Table 4 : Decomposing Risk Premia}

This table decomposes the increase in risk premia due to the presence of frictions to capital accumulation. In the model with costly external finance, we separate the effects attributable to changes in the pricing kernel and those attributable to changes in the default premium. Specifically, in the third line we compute $-\operatorname{Cov}_{t}\left(\log M_{t+1}^{f c}, \log R_{t, t+1}^{k, a c}\right)-0.5 \operatorname{Var}_{t}\left(\log R_{t, t+1}^{k, a c}\right)$ where $a c$ and $f c$ stand for the adjustment and financing cost economies respectively. In the fourth line we compute $-\operatorname{Cov}_{t}\left(\log M_{t+1}^{f c}, \log R_{t, t+1}^{k, f c}-\log R_{t, t+1}^{d}\right)-$ $0.5 \operatorname{Var}_{t}\left(\log R_{t, t+1}^{k, f c}-\log R_{t, t+1}^{d}\right)$. The premium in the (log) benchmark neoclassical model is normalized to 100 .

\begin{tabular}{lrc}
\hline \hline Effect & $\sigma=1$ & $\sigma=5$ \\
\hline & & \\
Benchmark Model & 100 & 129 \\
Adjustment Costs & 142 & 165 \\
& & \\
& Costly External Finance & 344 \\
Change in Pricing Kernel & 263 & -111 \\
Acyclical Default Premium & -37 & 2283 \\
All Features & 1729 & \\
\hline
\end{tabular}




\section{Figure 1 : Impulse Responses - Quantities}

This figure plots the impulse response of output, household consumption, household hours and investment to a technology shock. The solid lines are from the agency cost model and the dotted lines are from the standard adjustment cost model.
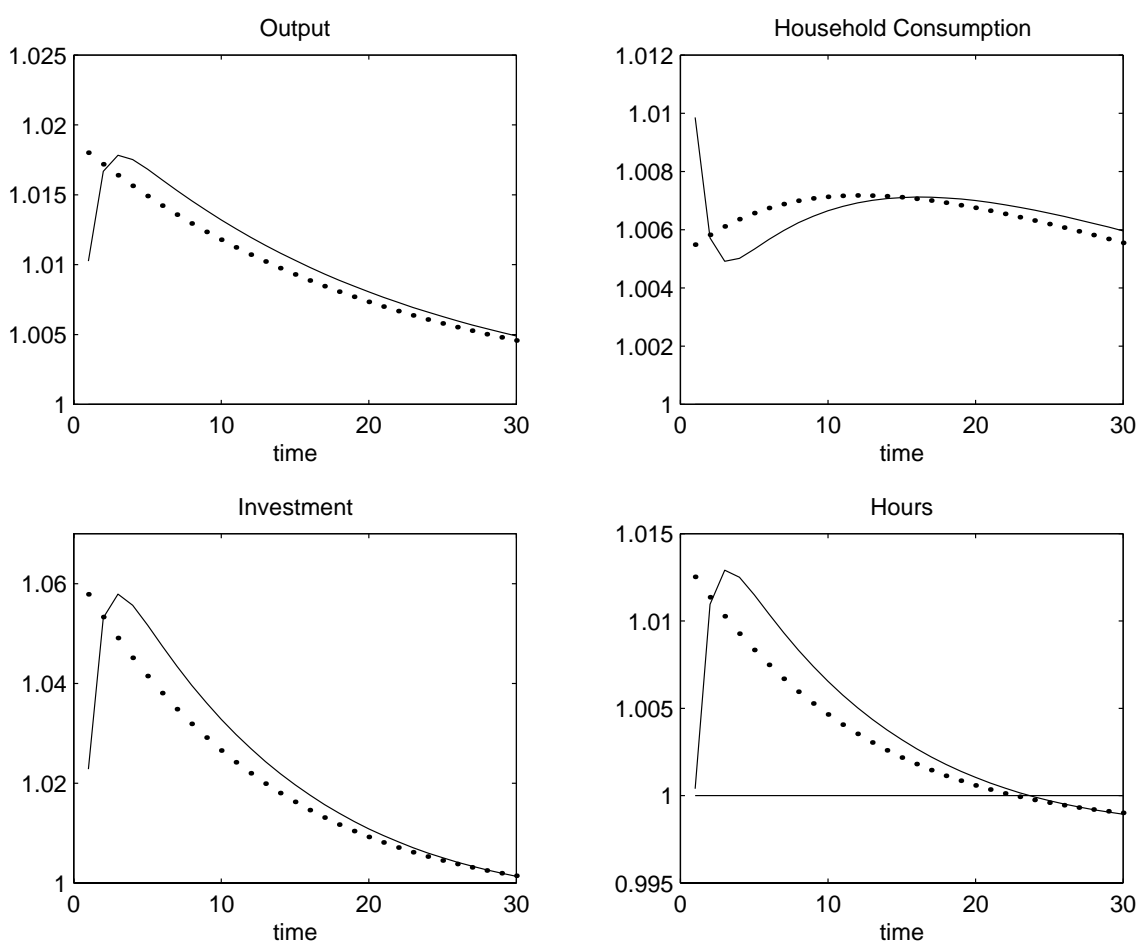


\section{Figure 2 : Impulse Responses - Asset Prices}

This figure plots the impulse response of the return of household capital $r_{t, t+1}^{k}$, the default premium $r_{t, t+1}^{d}$, investment to net worth, $i / n$, and Tobin's $Q$ to a technology shock. The solid lines are from the agency cost model and the dotted lines are from the standard adjustment cost model.
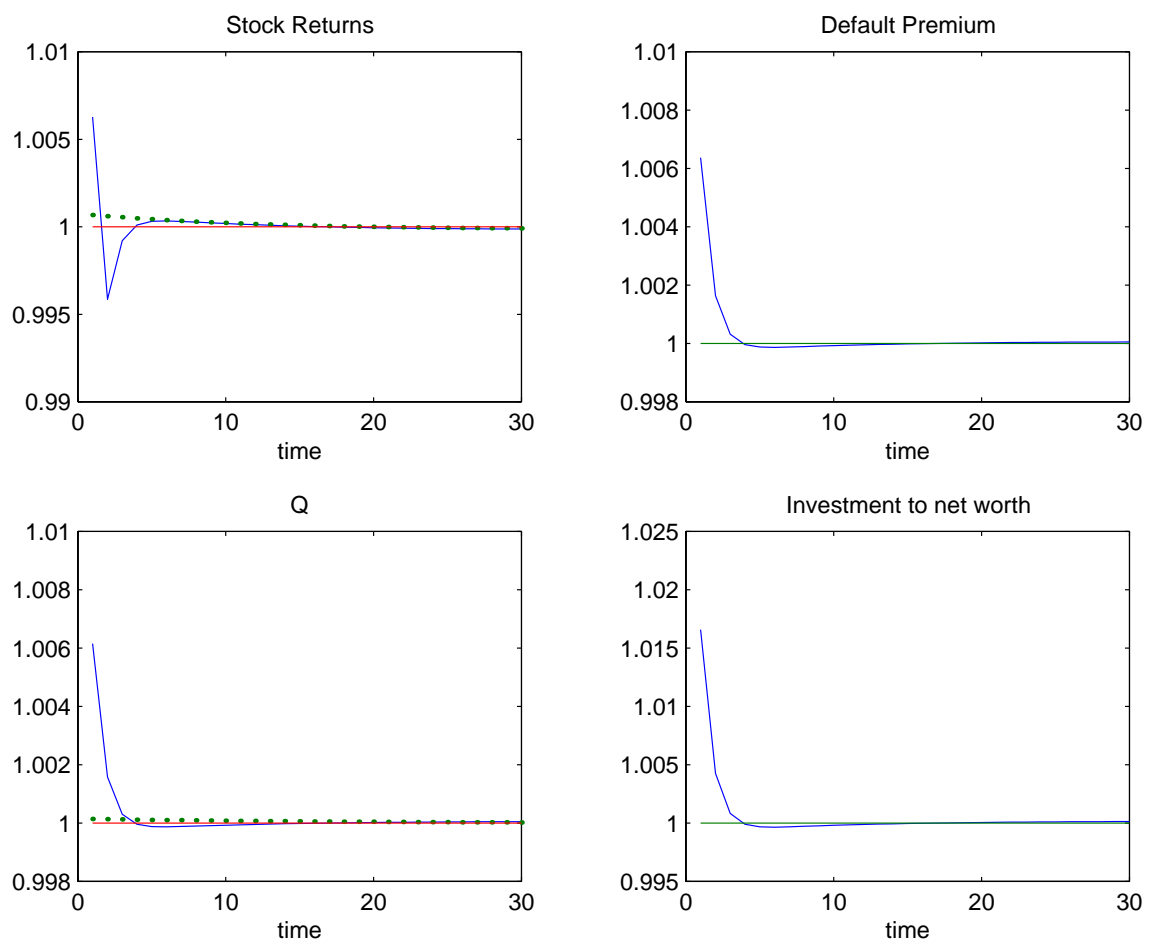
Figure 3 : Correlation Structure - Stock Returns $(a=.122$ and $\mu=.25)$

This figure presents the lead-lag correlations between the return on capital in the model and the investmentcapital ratio (Panel A) and the technology shocks (Panel B). The data denotes the CRSP value weighted returns.

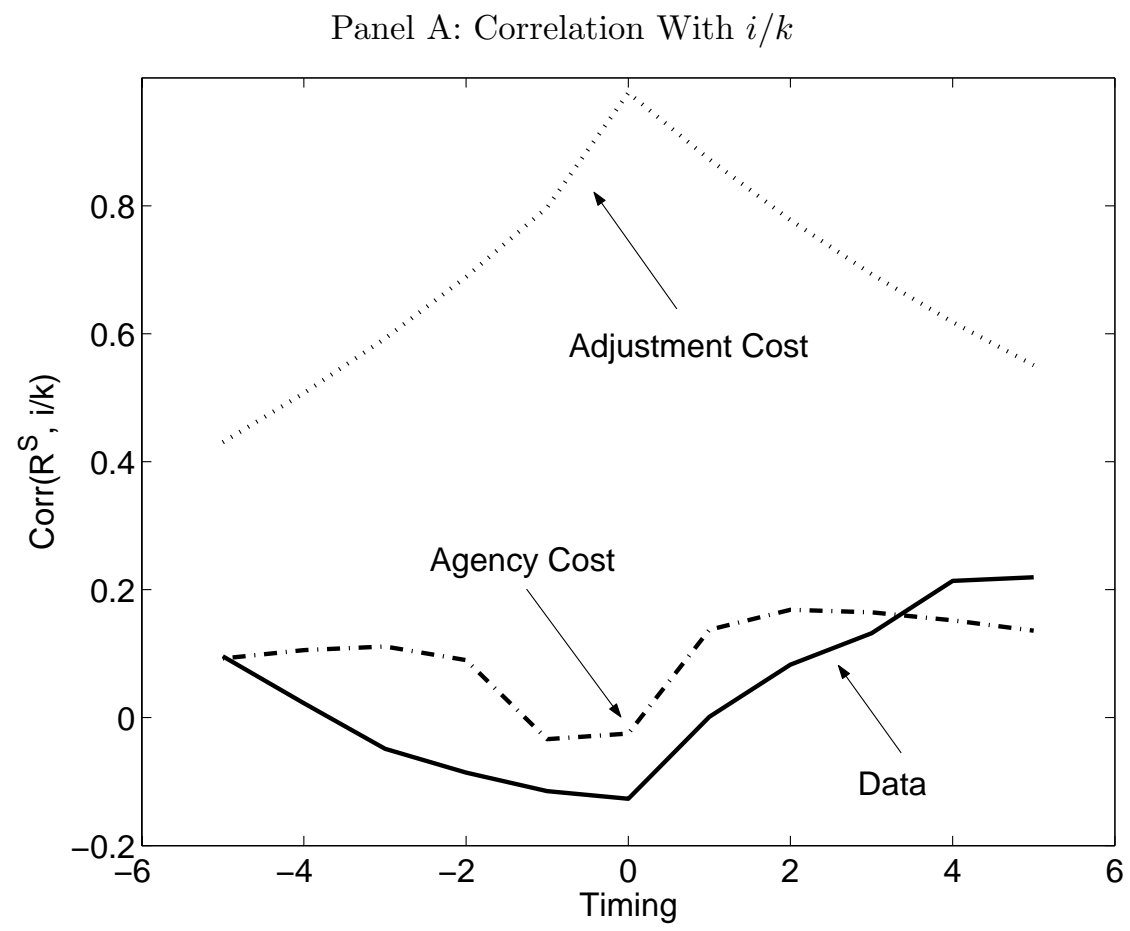

Panel B: Correlation with Productivity

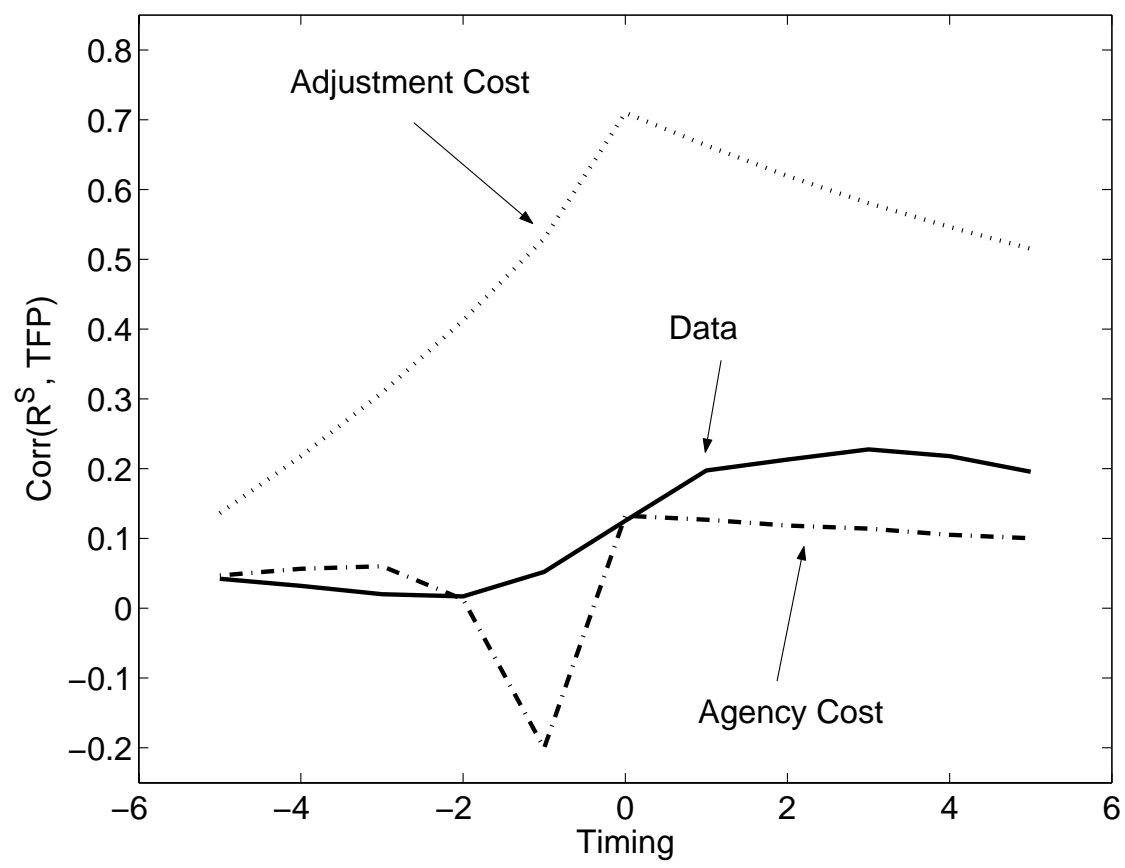


Figure 4 : Correlation Structure - Stock Returns $(a=20$ and $\mu=.05)$

This figure presents the lead-lag correlations between the return on capital in the model and the investmentcapital ratio (Panel A) and the technology shocks (Panel B). The data denotes the CRSP value weighted returns.
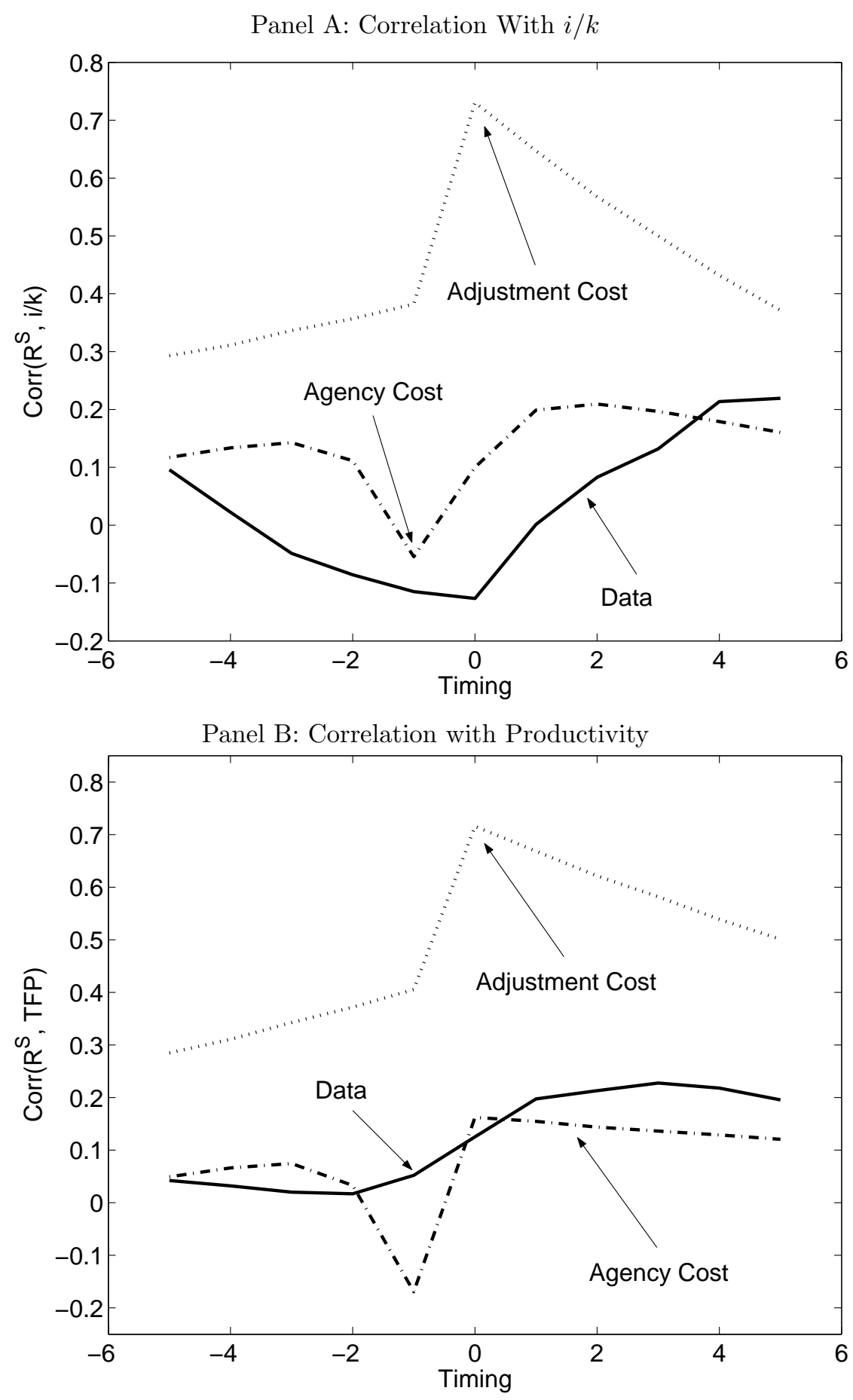


\section{Figure 5 : Correlation Structure - Default Premium I}

This figure presents the lead-lag correlations of the default premium with investment-capital ratio (Panel A) and total factor productivity (Panel B). The solid line uses our first measure of default premium in the data, defined as the yield spread between Baa and Aaa rated corporate bonds. The broken line is the implied default premium in the Agency Cost model.

Panel A: Correlation With $i / k$

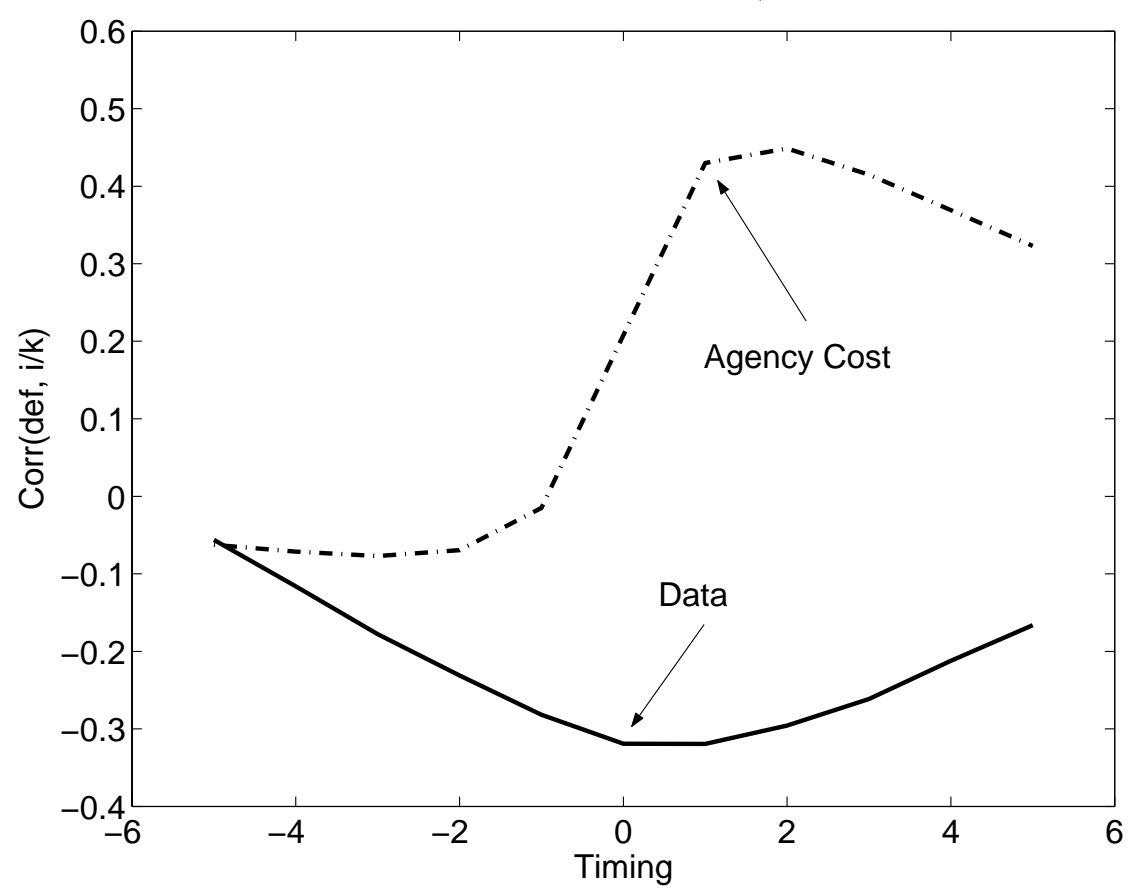

Panel B: Correlation with Productivity

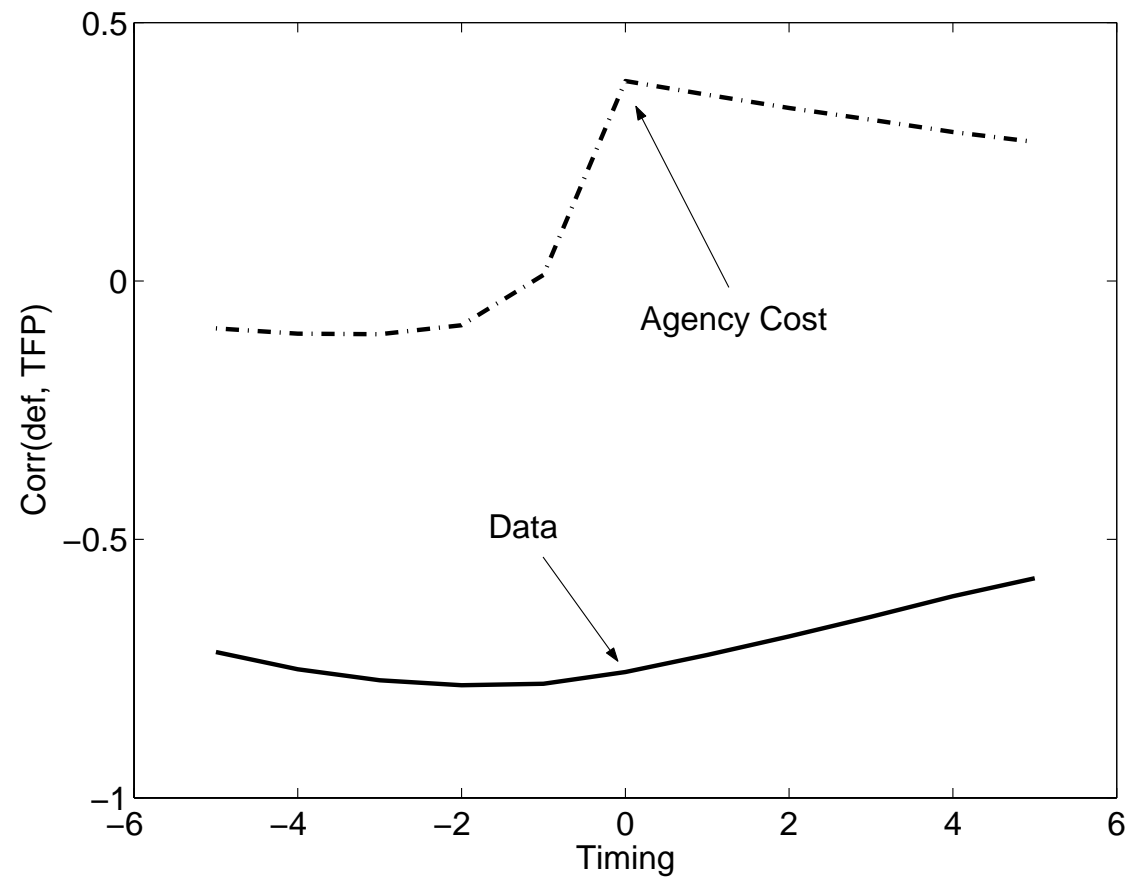




\section{Figure 6 : Correlation Structure — Default Premium II}

This figure presents the lead-lag correlations of the default premium with investment-capital ratio (Panel A) and total factor productivity (Panel B). The solid line uses our second measure of the default premium in the data, defined as the spread between prime bank loan rate and 3-month commercial paper rate. The broken line is the implied default premium in the Agency Cost model.

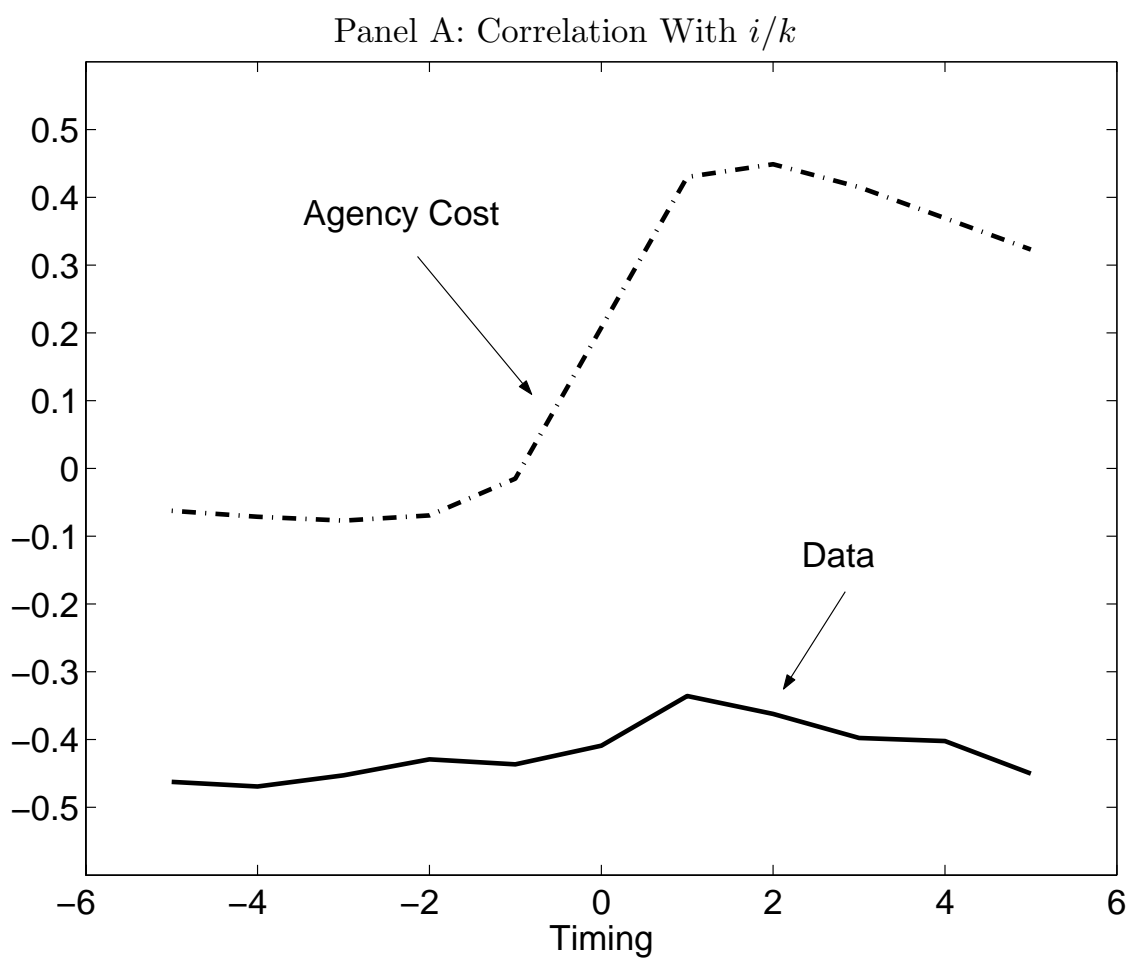

Panel B: Correlation with Productivity

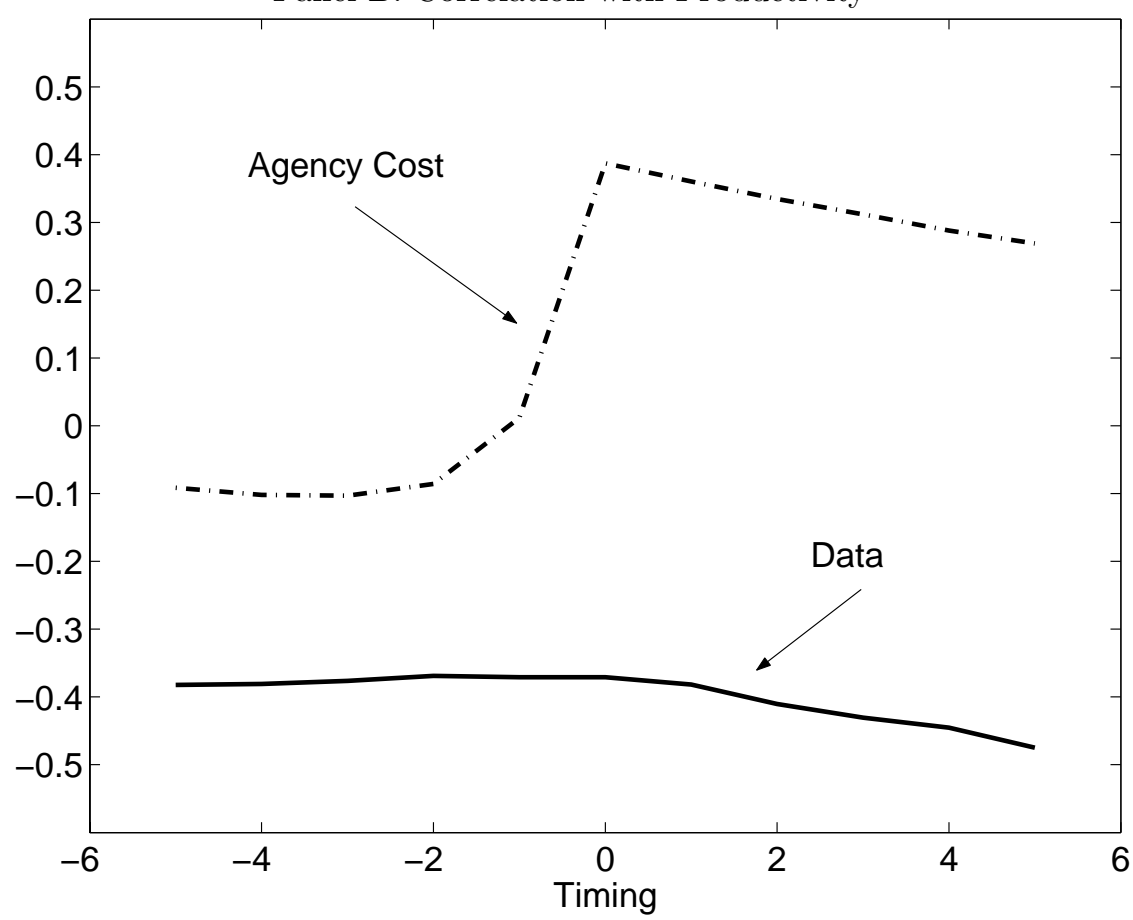


Figure 7 : Correlation Structure — Alternative Measures of Financing Premium

This figure presents the lead-lag correlations of the external financing premium with investment-capital ratio (Panel A) and with total factor productivity (Panel B). Three measures of external financing premium are presented: the Lamont, Polk, and Saá-Requejo (2001) measure (the star line), the Vassalou (2002) measure (the plus line), and the implied measure in the Agency Cost model (the broken line).

Panel A: Correlation With $i / k$

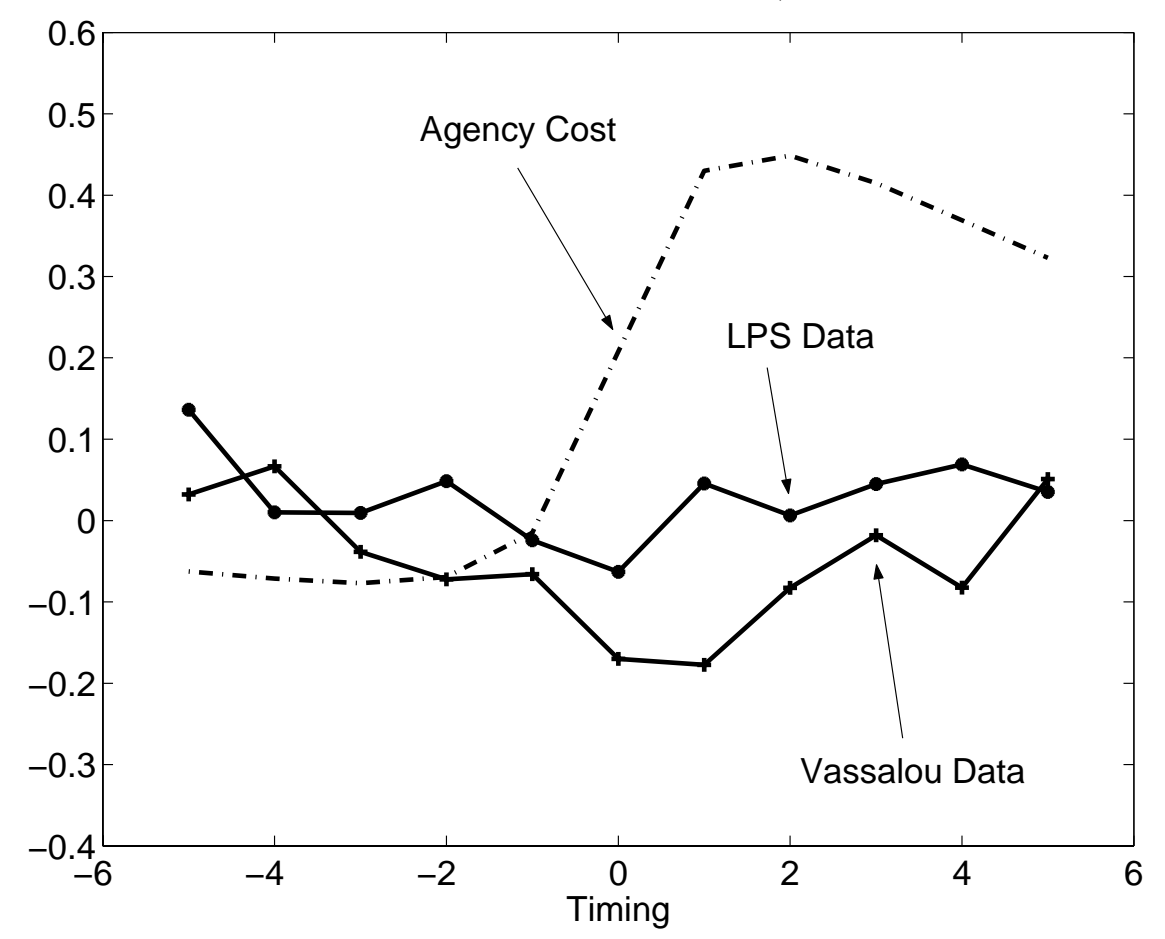

Panel B: Correlation with Productivity

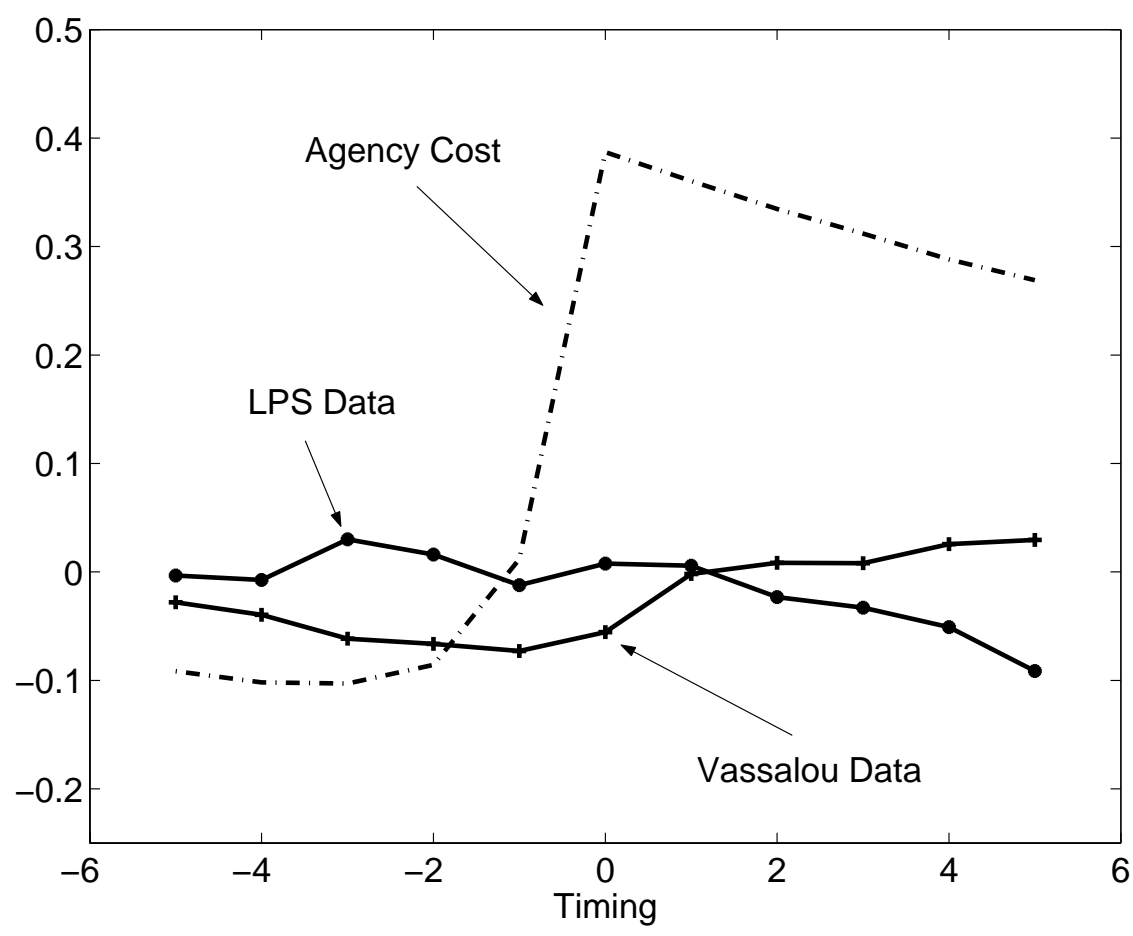

